\title{
EFFECT OF DEPTH OF HOUSE FLY PUPAE IN POULTRY MANURE ON PARASITISM BY SIX SPECIES OF PTEROMALIDAE (HYMENOPTERA) ${ }^{1}$
}

\author{
L. M. Rueda and R. C. Axtell \\ Department of Entomology \\ North Carolina State University \\ Raleigh, NC 27695-7613 \\ (Accepted for publication December 5, 1985)
}

\begin{abstract}
The recoveries of pteromalid parasites from house fly, Musca domestica L., pupae placed in accumulated poultry manure at the surface and at depths of $3,5,10$ and $15 \mathrm{~cm}$ were determined weekly for 10 weeks in two types of caged-layer poultry houses. No parasites were recovered from fly pupae at the $15 \mathrm{~cm}$ depth. Muscidifurax raptor Girault and Sanders and Pachycrepoideus vindemiae (Rondani) were the first and second most abundant house fly pupal parasites collected on the surface and $3 \mathrm{~cm}$ beneath the surface of the poultry manure in narrow and high-rise caged-layer poultry houses. From house fly pupae $5 \mathrm{~cm}$ deep, $P$. vindemiae was rarely recovered while 5 to $12 \%$ of the parasites recovered at that depth were $M$. raptor. Spalangia cameroni Perkins was the most abundant Spalangia species and was recovered mostly from pupae at 5 and $10 \mathrm{~cm}$ deep in the manure in both houses. Other, less abundant, Spalangia species ( $S$. endius Walker and $S$. nigroaenea Curtis) were recovered from fly pupae to a depth of $10 \mathrm{~cm}$ beneath the manure surface in both houses. Muscidifurax zaraptor, an introduced species, was released in the narrow caged-layer poultry house, and was recovered from pupae on the surface and $3 \mathrm{~cm}$ deep in the manure.
\end{abstract}

Key Words: House fly, fly parasites, Pteromalidae, Muscidifurax, Spalangia, Musca domestica, .

J. Entomol. Sci. 20(4): 444-449 (October 1985)

\section{INTRODUCTION}

Pupae of the house fly and other muscoid filth flies in poultry and livestock manure are attacked by parasitic species of Hymenoptera, belonging mainly to the family Pteromalidae (Legner et al. 1967; Rueda and Axtell 1985a,b; Rutz and Axtell $1979,1980)$. The species of parasites exhibit differences in their ability to search for host pupae in a particular habitat. Muscidifurax species have been reported to be more common parasitizing fly pupae on or near the surface of accumulated manure and Spalangia species to be more common parasitizing pupae at various levels of manure, mostly in deeper areas (Legner and Brydon 1966; Legner 1977, 1983; Morgan et al. 1981). Under laboratory conditions, Legner (1977) investigated the depth of search by various strains of pupal parasites using wheat flakes as an artificial habitat. However, field experiments under more natural conditions have not been conducted to determine the depths in manure at which pteromalid parasites will parasitize fly puape. Therefore, the present study was undertaken to determine the degree of parasitism by naturally-occurring populations of pteromalid parasites of house fly pupae buried at various depths in poultry manure.

1 Paper No. 1093 of the Journal Series of the North Carolina Agricultural Research Service, Raleigh, NC 27695-7601. 


\section{MATERIALS AND METHODS}

The study was conducted at a narrow or California type and a high-rise type of caged-layer poultry houses located in Wake and Granville Counties, North Carolina, respectively. The narrow caged-layer poultry house was an open-sided structure (40 m long $\times 3 \mathrm{~m}$ wide; 1,000 bird capacity) with one row of two-tiered wire stairstep cages, 2 to 3 birds per cage, suspended $1 \mathrm{~m}$ above a dirt floor running the length of the house along the side of a single concrete walkway. The high-rise house (or deep pit house) was a two-story open-sided structure with a 25,000 bird capacity. Birds were held in the second story in rows of four-tiered wire stairstep cages (3 to 4 birds/cage) which ran the length of the house along each of four wooden aisles. The manure accumulated on the first floor.

The experiments were conducted with intact cores of manure placed in cylindrical, open-top, screen wire cages $(10 \mathrm{~cm}$ Diam, $15 \mathrm{~cm}$ high, $2 \times 2 \mathrm{~mm}$ openings) inserted in the piled manure under the caged birds. Using a cylindrical soil sampler, a core of manure on the dirt floor was removed and transferred intact into the cylindrical wire cage. The manure in the experimental area was about 20 to $25 \mathrm{~cm}$ deep. Each of the cages was marked either $0,3,5,10$ or $15 \mathrm{~cm}$ to represent the depth of pupal location. Pupal bags $(3 \times 3 \mathrm{~cm}$, made from screen with $2 \times 2 \mathrm{~mm}$ openings) each containing 30 laboratory-reared house fly pupae $(<1$-day old) were used to monitor the parasite activity at the various depths. At the time the core of manure was added, a pupal bag was inserted horizontally at one of the specific depth marks in each cage. The cage was then lowered into the same hole in the manure pile from which the manure in the cage was previously taken and the surrounding area was covered with manure to seal any gaps around the cage. The cages were about $1.5 \mathrm{~m}$ apart. Pupal bags were collected after a 1-week exposure and new bags were positioned similarly in the manure of the cages. The manure core sample in each cage was replaced every other week with a new sample from a nearby area to minimize hardening or caking of the manure which might interfere with the penetration or searching ability of the parasites. A randomized complete block design was used and treatments were replicated eight times. This was repeated for 10 weeks (August to October 1982) in both types of poultry houses. Pupae from the recovered pupal bags were held in the laboratory for 35 to 50 days at $26.7^{\circ} \mathrm{C}$ and $60 \pm 5 \% \mathrm{RH}$ to allow time for parasite development and emergence.

Muscidifurax zaraptor Kogan and Legner was released in the narrow house during this study. These were cultured from a colony originally established from specimens collected near Denver, CO, and were provided by E. F. Legner, Univ. California, Riverside. We reared the species on house fly pupae and released 54,000 on 2 August, 17,000 on 9 August, 31,000 on 23 August, 14,000 on 6 September, and 29,000 on 20 September.

\section{RESULTS AND DISCUSSION}

Muscidifurax raptor Girault and Sanders was the most abundant species recovered from pupae placed on the surface and $3 \mathrm{~cm}$ beneath the surface of the poultry manure both in the narrow and the high-rise types of caged-layer poultry houses (Tables 1 and 2). The percentages of $M$. raptor among all the parasites recovered were 56.1 and $39.7 \%$ on the surface and $3 \mathrm{~cm}$ beneath the surface, 
Table 1. Relative abundance of pteromalid parasites (Hymenoptera) that emerged from house fly pupae exposed in pupal bags in manure at various depths in a narrow type of caged-layer poultry house, August-October 1982.

\begin{tabular}{|c|c|c|c|c|c|c|}
\hline \multirow[b]{3}{*}{ Species } & \multicolumn{5}{|c|}{$\begin{array}{c}\% \text { of a species at each depth } \\
\text { (\% relative abundance })\end{array}$} & \multirow{3}{*}{$\begin{array}{l}\text { Total no } \\
\text { collected }\end{array}$} \\
\hline & \multicolumn{5}{|c|}{ Depth $(\mathrm{cm})$} & \\
\hline & 0 & 3 & 5 & 10 & 15 & \\
\hline Muscidifurax raptor & $\begin{array}{c}64.4^{*} \\
(56.1)^{\dagger}\end{array}$ & $\begin{array}{c}30.1 \\
(39.7)\end{array}$ & $\begin{array}{c}5.4 \\
(12.1)\end{array}$ & $\begin{array}{c}0.0 \\
(0.0)\end{array}$ & $\begin{array}{l}0.0 \\
(0.0)\end{array}$ & 624 \\
\hline M. zaraptor & $\begin{array}{c}69.9 \\
(18.1)\end{array}$ & $\begin{array}{c}30.1 \\
(11.8)\end{array}$ & $\begin{array}{c}0.0 \\
(0.0)\end{array}$ & $\begin{array}{c}0.0 \\
(0.0)\end{array}$ & $\begin{array}{c}0.0 \\
(0.0)\end{array}$ & 186 \\
\hline Spalangia cameroni & $\begin{array}{c}1.3 \\
(1.0)\end{array}$ & $\begin{array}{c}26.6 \\
(30.4)\end{array}$ & $\begin{array}{l}39.8 \\
(76.9)\end{array}$ & $\begin{array}{c}32.3 \\
(86.2)\end{array}$ & $\begin{array}{l}0.0 \\
(0.0)\end{array}$ & 542 \\
\hline S. endius & $\begin{array}{c}0.0 \\
(0.0)\end{array}$ & $\begin{array}{l}44.0 \\
(6.9)\end{array}$ & $\begin{array}{l}26.7 \\
(7.1)\end{array}$ & $\begin{array}{c}29.3 \\
(10.8)\end{array}$ & $\begin{array}{c}0.0 \\
(0.0)\end{array}$ & 75 \\
\hline S. nigroaenea & $\begin{array}{c}0.0 \\
(0.0)\end{array}$ & $\begin{array}{l}50.0 \\
(3.6)\end{array}$ & $\begin{array}{c}32.3 \\
(3.9)\end{array}$ & $\begin{array}{l}17.6 \\
(2.9)\end{array}$ & $\begin{array}{c}0.0 \\
(0.0)\end{array}$ & 34 \\
\hline $\begin{array}{c}\text { Pachycrepoideus } \\
\text { vindemiae }\end{array}$ & $\begin{array}{c}83.2 \\
(24.8)\end{array}$ & $\begin{array}{l}16.8 \\
(7.6)\end{array}$ & $\begin{array}{c}0.0 \\
(0.0)\end{array}$ & $\begin{array}{c}0.0 \\
(0.0)\end{array}$ & $\begin{array}{l}0.0 \\
(0.0)\end{array}$ & 214 \\
\hline Total no. collected & 717 & 474 & 281 & 203 & 0 & \\
\hline$\%$ parasitism $\neq$ & 32.4 & 20.8 & 12.8 & 9.6 & 0 & \\
\hline
\end{tabular}

${ }^{*}$ Percentage of each species at each depth calculated using the total number of specimens of that species collected at all depths.

$\uparrow$ Relative abundance percentages at each depth calculated using the total number of specimens of all species collected at that depth.

‡ Percentage of exposed house fly pupae from which adult parasites emerged.

respectively, in the narrow caged-layer house, and $47.8 \%$ (on the surface) and $44.5 \%$ ( $3 \mathrm{~cm}$ deep) in the high-rise caged-layer house. Muscidifurax raptor also was recovered in the area $5 \mathrm{~cm}$ beneath the manure surface but not at the greater depths. Pachycrepoideus vindemiae (Rondani) was the second most abundant species collected on the surface of the manure. It comprised 24.8 and $48.3 \%$ of all parasites recovered in the narrow and high-rise caged-layer houses, respectively. Pachycrepoideus vindemiae was recovered from pupae placed $3 \mathrm{~cm}$ deep in the manure but was rarely recovered from pupae at greater depths. Spalangia cameroni Perkins was recovered mostly from pupae placed at 5 and $10 \mathrm{~cm}$ beneath the manure surface in both houses; small numbers were recovered from pupae placed on the surface and at $3 \mathrm{~cm}$ depth. The other species of Spalangia were less abundant in the houses. Spalangia endius and $S$. nigroaenea were recovered in low numbers on the surface (especially in the high-rise houses), and most were recovered from pupae 3 to $10 \mathrm{~cm}$ deep in the manure in both houses. Muscidifurax zaraptor, a species introduced into the narrow caged-layer house, was recovered from pupae placed on the surface and $3 \mathrm{~cm}$ deep in the manure. It comprised about 18.1 and $11.8 \%$ of all parasites collected from pupae exposed on the surface and $3 \mathrm{~cm}$ deep, respectively. Muscidifurax zaraptor was not recovered at the high-rise poultry houses where no releases had been made. 
Table 2. Relative abundance of pteromalid parasites (Hymenoptera) that emerged from house fly pupae exposed in pupal bags in manure at various depths in a high-rise type of caged-layer poultry house, August-October 1982.

\begin{tabular}{|c|c|c|c|c|c|c|}
\hline \multirow[b]{3}{*}{ Species } & \multicolumn{5}{|c|}{$\begin{array}{c}\% \text { of a species at each depth } \\
(\% \text { relative abundance })\end{array}$} & \multirow{3}{*}{$\begin{array}{l}\text { Total no } \\
\text { collected }\end{array}$} \\
\hline & \multicolumn{5}{|c|}{ Depth (cm) } & \\
\hline & 0 & 3 & 5 & 10 & 15 & \\
\hline Muscidifurax raptor & $\begin{array}{l}53.3^{*} \\
(47.8)^{+}\end{array}$ & $\begin{array}{l}34.0 \\
(44.5)\end{array}$ & $\begin{array}{l}12.8 \\
(20.4)\end{array}$ & $\begin{array}{c}0.0 \\
(0.0)\end{array}$ & $\begin{array}{c}0.0 \\
(0.0)\end{array}$ & 760 \\
\hline M. zaraptor & $\begin{array}{c}0.0 \\
(0.0)\end{array}$ & $\begin{array}{c}0.0 \\
(0.0)\end{array}$ & $\begin{array}{c}0.0 \\
(0.0)\end{array}$ & $\begin{array}{c}0.0 \\
(0.0)\end{array}$ & $\begin{array}{c}0.0 \\
(0.0)\end{array}$ & 0 \\
\hline Spalangia cameroni & $\begin{array}{c}2.9 \\
(1.2)\end{array}$ & $\begin{array}{l}27.9 \\
(16.3)\end{array}$ & $\begin{array}{c}47.5 \\
(34.1)\end{array}$ & $\begin{array}{c}21.7 \\
(39.1)\end{array}$ & $\begin{array}{c}0.0 \\
(0.0)\end{array}$ & 341 \\
\hline S. endius & $\begin{array}{l}12.7 \\
(2.2)\end{array}$ & $\begin{array}{l}30.2 \\
(7.7)\end{array}$ & $\begin{array}{c}42.9 \\
(13.5)\end{array}$ & $\begin{array}{c}14.1 \\
(11.1)\end{array}$ & $\begin{array}{c}0.0 \\
(0.0)\end{array}$ & 149 \\
\hline S. nigroaenea & $\begin{array}{c}1.2 \\
(0.5)\end{array}$ & $\begin{array}{c}29.7 \\
(17.2)\end{array}$ & $\begin{array}{c}41.2 \\
(29.3)\end{array}$ & $\begin{array}{c}27.9 \\
(49.7)\end{array}$ & $\begin{array}{c}0.0 \\
(0.0)\end{array}$ & 337 \\
\hline $\begin{array}{c}\text { Pachycrepoideus } \\
\text { vindemiae }\end{array}$ & $\begin{array}{c}81.0 \\
(48.3)\end{array}$ & $\begin{array}{c}16.4 \\
(14.3)\end{array}$ & $\begin{array}{l}2.6 \\
(2.7)\end{array}$ & $\begin{array}{c}0.0 \\
(0.0)\end{array}$ & $\begin{array}{l}0.0 \\
(0.0)\end{array}$ & 505 \\
\hline Total no. collected & 847 & 581 & 475 & 189 & 0 & \\
\hline$\%$ parasitism $\neq$ & 38.2 & 26.1 & 21.5 & 8.4 & 0.0 & \\
\hline
\end{tabular}

The rate of parastism of the fly pupae was highest at the surface of the manure (32.4 and $38.2 \%$ at narrow and high-rise houses, respectively) and decreased proportionally with depth (down to $10 \mathrm{~cm}$ ). In these experiments, no parasites were recovered from the fly pupae placed $15 \mathrm{~cm}$ deep in the manure.

Our data indicate that $M$. raptor, $M$. zaraptor and $P$. vindemiae mostly confine their search for host pupae on and $3 \mathrm{~cm}$ beneath the surface of poultry manure. This agrees with the observations by Legner $(1977,1983)$ that species of Muscidifurax are prevalent in or near the surface of the habitat. However, Morgan et al. (1981) reported that $M$. raptor does not parasitize pupae more than $1 \mathrm{~mm}$ below the surface of the manure in poultry houses in Florida. This is in contrast with our data which shows that $M$. raptor was recovered from host pupae down to $5 \mathrm{~cm}$ beneath the surface of the manure. There may be differences among strains of parasites in their abilities to penetrate manure and locate fly pupae. Also, the environmental conditions and manure consistency probably affect the abilities of the parasites to locate pupae. Under laboratory conditions using wheat flakes as media, Legner (1977) found that the California strain of $M$. zaraptor searched for the host pupae near the surface of the medium while a New Mexico strain of the same species penetrated deeper into the medium under dry conditions. Our data indicate that Spalangia species, such as $S$. cameroni, $S$. endius and $S$. nigroaenea, are able to locate fly pupae at various depths in the manure but mostly confine their search to the greater depths which are almost or beyond the reach of 
Muscidifurax and Pachycrepoideus species. Spalangia were more active against fly pupae at 3 to $10 \mathrm{~cm}$ depths while the other genera were most active at 0 to $3 \mathrm{~cm}$ depths.

No specimens of $S$. cameroni were recovered from pupae exposed on the surface of the manure at the narrow caged-layer house. The release of $M$. zaraptor, a highly competitive species (Wylie 1971; Coats 1976), could possibly have caused the Spalangia species to seek host pupae in the deeper habitat. Females of $M$. zaraptor often do not discriminate house fly pupae parasitized by Spalangia species (Wylie 1971), and in most cases the highly cannibalistic larva of M. zaraptor out-competes other larvae and survives superparasitism by other species (Coats 1976). It should be noted that $M$. zaraptor is not known to occur naturally in North Carolina.

Furthermore, $M$. raptor does not avoid pupae parasitized by $S$. endius whereas $S$. endius usually avoids pupae parasitized by $M$. raptor (Propp and Morgan 1983). Like $M$. zaraptor, larvae of $M$. raptor usually compete with larvae of other species in the same host. Larvae of $S$. endius, $S$. cameroni and $S$. nigra are competitively inferior and females are less aggressive compared to Muscidifurax species and $P$. vindemiae (Legner 1977).

Because $M$. raptor, $M$. zaraptor and $P$. vindemiae, the prevalent seekers of fly pupae on or near the manure surface, can utilize hosts which have been parasitized by Spalangia species, it may be advantageous for Spalangia species to concentrate their effort deeper in the manure. Theoretically, it should be advantageous to simultaneously release parasites which seek pupae in or near the manure surface (e.g. Muscidifurax species or $P$. vindemiae) and species which seek pupae at greater depths (e.g. $S$. cameroni, $S$. endius or $S$. nigroaenea) to increase the effectiveness of a parasite-release program in suppressing house fly populations in poultry houses.

\section{LITERATURE CITED}

Coats, S. A. 1976. Life cycle and behavior of Muscidifurax zaraptor (Hymenoptera: Pteromalidae). Ann. Entomol. Soc. Am. 60: 772-780.

Legner, E. F. 1977. Temperature, humidity and depth of habitat influencing host destruction and fecundity of muscoid fly parasites. Entomophaga 22: 199-206.

Legner, E. F. 1983. Broadened view of Muscidifurax parasites associated with endophilous synanthropic flies and sibling species in the Spalangia endius complex. Proc. Calif. Mosq. and Vect. Contr. Assoc. 51: 41-42.

Legner, E. F., E. C. Bay, and E. B. White. 1967. Activity of parasites from Diptera: Musca domestica, Stomoxys calcitrans, Fannia canicularis and $F$. femoralis, at sites in the Western Hemisphere. Ann. Entomol. Soc. Am. 60: 462-468.

Legner, E. F., and H. W. Brydon. 1966. Suppression of dung-inhabiting fly populations by pupal parasites. Ann. Entomol. Soc. Am. 59: 638-651.

Morgan, P. B., D. E. Weidhaas, and R. S. Patterson. 1981. Program releases of Spalangia endius and Muscidifurax raptor (Hymenoptera: Pteromalidae) against estimated populations of Musca domestica (Diptera: Muscidae). J. Med. Entomol. 18: 158-166.

Propp, G. D., and P. B. Morgan. 1983. Multiparasitism of house fly, Musca domestica L., pupae by Spalangia endius and Muscidifurax raptor Girault and Sanders (Hymenoptera: Pteromalidae). Environ. Entomol. 12: 1232-1238.

Rueda, L. M., and R. C. Axtell. 1985a. Comparison of hymenopterous parasites of house fly, Musca domestica (Diptera: Muscidae), pupae in different livestock and poultry production systems. Environ. Entomol. 14: 217-222. 
Rueda, L. M., and R. C. Axtell. 1985b. Guide to common species of pupal parasites (Hymenoptera: Pteromalidae) of the house fly and other muscoid flies associated with poultry and livestock manure. North Carolina Agri. Res. Serv. Tech. Bull. 278. 88 pp.

Rutz, D. A., and R. C. Axtell. 1979. Sustained releases of Muscidifurax raptor (Hymenoptera: Pteromalidae) for house fly (Musca domestica) control in two types of caged-layer poultry houses. Environ. Entomol. 8: 1105-1110.

Rutz, D. A., and R. C. Axtell. 1980. Invasion and establishment of house fly, Musca domestica (Diptera: Muscidae), parasites (Hymenoptera: Pteromalidae) in caged layer poultry houses. J. Med. Entomol. 17: 151-155.

Wylie, H. G. 1971. Oviposition restraint of Muscidifurax zaraptor (Hymenoptera: Pteromalidae) on parasitized house fly pupae. Can. Entomol. 103: 1537-1544. 